\title{
Fungi influenced corrosion on nitrocarburized multiphase 4340 steel
}

\author{
Corrosão em aço 4340 multifásico nitrocarburado influenciada por fungos \\ Sabrina de Moura Rovetta ${ }^{1,2}$, Antonio Jorge Abdalla ${ }^{2}$, Vladimir Henrique Baggio Scheid ${ }^{2}$, \\ Sonia Khouri ${ }^{1}$, Choiu Otani ${ }^{3}$, Walter Miyakawa ${ }^{2}$
}

\begin{abstract}
Corrosion on multiphase steels is strongly influenced by the iron content. On the other hand, thermochemical surface treatments like plasma nitrocarburizing have been successfully used to enhance resistance to saltspray corrosion, but the literature about microbial influenced corrosion is still scarce. The aim of this work was then to evaluate the biocorrosion influenced by the Penicillium candidum fungus on plasma nitrocarburized multiphase 4340 steel, comparatively with the untreated steel. Small blocks of treated and untreated metals were evaluated by SEM, AFM, and EDS, before and after the biocorrosion process. It was observed that biocorrosion drastically affected the surface of the untreated 4340 steel while nitrocarburized samples preserved their original aspect. Only $7 \%$ of oxide content was detected in the nitrocarburized steel against $32 \%$ in the untreated metal. It was concluded that plasma nitrocarburing was effective to improve biocorrosion resistance of multiphase 4340 steel, and consequently, this treatment should be also tested with other microorganisms and in other metals and alloys used in the aerospace and aviation industries.
\end{abstract}

Keywords: Biocorrosion; Fungi; Penicillium candidum; 4340 steel; AFM.

\section{Resumo}

Corrosão em aços multifásicos é fortemente influenciada pelo teor de ferro. Por outro lado, os tratamentos de superficie termoquímicos como a nitrocarburação a plasma têm sido utilizados com sucesso para aumentar a resistência à corrosão salt-spray, mas a literatura sobre a corrosão influenciada por microorganismos ainda é escassa. O objetivo deste trabalho foi avaliar a biocorrosão influenciada pelo fungo Penicillium candidum em aço multifásico 4340 após o tratamento de nitrocarburação a plasma comparado com o aço sem tratamento. Pequenos blocos de aço com e sem tratamento foram avaliadas por SEM, AFM, e EDS, antes e depois do processo de biocorrosão. Observou-se que a biocorrosão afetou drasticamente a superficie do aço 4340 sem tratamento, enquanto as amostras nitrocarburadas teve o seu aspecto original preservado. Foi detectado apenas $7 \%$ de teor de óxido no aço nitrocarburado contra $32 \%$ no aço não tratado. Concluiu-se que a nitrocarburação a plasma foi eficaz para melhorar a resistência a biocorrosão de aço multifásico 4340, e, consequentemente, este tratamento deve ser testado com outros microorganismos e em outros metais e ligas utilizadas na indústria aeroespacial e de aviação.

Palavras-chave: Biocorrosão; Fungos; Penicillium candidum; Aço 4340; AFM.

\footnotetext{
${ }^{1}$ Universidade do Vale do Paraíba - São José dos Campos/SP - Brazil ${ }^{2}$ Instituto de Estudos Avançados - São José dos Campos/SP - Brazil

${ }^{3}$ Instituto Tecnológico de Aeronáutica - São José dos Campos/SP - Brazil

Autor correspondente: Antonio Jorge Abdalla. Email: abdalla@ieav.cta.br
} 


\section{Introduction}

Multiphase steels are widely used in industry, usually in structural applications for automotive, aerospace and defense industries. However, despite the high technology involved in their production, multiphase steels are susceptible to corrosion, mainly due to the significant iron content. Thermochemical surface treatments as plasma nitrocarburizing has been considered effective to enhance some specific properties such as corrosion resistance, hardness, friction wear, fatigue life ${ }^{(1-4)}$, and in fact, improvement on corrosion resistance and high surface hardness have been reported after these treatments ${ }^{(4)}$. However, the effects of microorganisms on multiphase steels corrosion processes are scarcely studied.

Biocorrosion is the term commonly used to designate an electrochemical process of metal dissolution due to the presence of bacteria, microalgae, and fungi $i^{(1)}$, that act as a consortium of microorganisms ${ }^{(1)}$. In this microbiologically influenced process, metabolites and acidic by-products alter the metal-solution interface, initiating, facilitating or enhancing the corrosion process.

Many investigations have focused in microorganisms of jet fuel systems ${ }^{(7-9)}$, where both bacteria and fungi are usually found. However, fungal growth has also been observed in aircrafts passenger compartments ${ }^{(10)}$, where biocorrosion is also a matter of concern.

Fungi $i^{(5,11)}$ are eukaryotic microorganisms, with a thick and rigid cellular wall. The filamentous fungi growth is ramified (mycelium) in single tubular multinucleate structures (hyphae), originated from the germination of reproductive spores. Morphologically more complex compared with the bacteria cells, the vegetative mycelium is responsible for the fungi adherence in solid substrates, while spores are formed in aerial hyphae.

The filamentous fungus Penicillium candidum used in this work belongs to the saprophytic specie. During their life-cycle, the $P$. candidum hydrolyzes ester bonds to produce mono- and diacylglycerols, glycerol, and organic and free fatty acids ${ }^{(12,13)}$, which are corrosive substances. This fungus was chosen because it has been implicated in corrosion processes as much as the genus Aspergillus ${ }^{(14-16)}$.

The aim of this work was to evaluate the biocorrosion on plasma nitrocarburized multiphase 4340 steel influenced by the fungi Penicillium candidum, comparatively with the untreated 4340 steel.

\section{Materials and Methods}

Sample preparation

Coupons ( $5 \mathrm{~mm} \times 5 \mathrm{~mm} \times 3 \mathrm{~mm}$ ) were cut from a plate of AISI 4340 steel. Five pieces were metallographically polished and acid-etched with 5\% Nital solution for 10 seconds. Another set of coupons have their surfaces nitrocarburized in a DC-pulsed plasma discharge, in a $75 \% \mathrm{~N}_{2}, 23.5 \% \mathrm{H}_{2}$ and $1.5 \% \mathrm{CH}_{4}$ atmosphere, for three hours, at temperature of $500^{\circ} \mathrm{C}$. Both treated and untreated coupons have their surfaces evaluated by SEM-scanning electron microscopy (LEO 1460Vp, Carl Zeiss, USA) and by AFM-atomic force microscopy (SPM 9500J3, Shimadzu, Japan), in contact mode, using conventional SiNi probes. Surface chemical microanalyses were also performed by EDS-energy dispersive spectroscopy (X-MAX EDS, Oxford Instruments, UK).

\section{Biocorrosion}

Lyophilized P. candidum (PC-TT033, CHR HASEN, Denmark) was revitalized in sterile distilled water and a pure culture was grown in Sabouraud Dextrose agar (Himedia, India). From this pure culture, a fungal spore suspension $(1.50 \times 105$ spores $/ \mathrm{ml})$ was prepared in a glass tube with sterile distilled water. Next, a set of glass tubes with $3 \mathrm{ml}$ of Sabouraud Dextrose broth (Himedia, India) was inoculated with $100 \mu \mathrm{l}$ of the prepared spore suspension. One coupon was immersed in each tube. The tubes were kept at a constant temperature of $25^{\circ} \mathrm{C}$ for 14 days. After this incubation period, samples were evaluated using the same techniques (SEM, AFM and EDS).

\section{Results and Discussion}

Figure 1a shows a characteristic image of the untreated 4340 steel surface obtained by SEM. Typical cementite microstructures (needle-shaped $\mathrm{Fe}_{3} \mathrm{C}$ ) can be seen over the ferrite matrix ( $\alpha$-Fe, dark regions). Some bainite plates can also be visualized (dashed white circles). It is important to notice that after the plasma nitrocarburizing, these microstructures could no longer be identified (Fig. 1b).

Representative AFM bi-dimensional images with $40 \mu \mathrm{m} \times 40 \mu \mathrm{m}$ of scanning area of the same untreated 4340 steel samples are presented in Fig. 2. In addition 
to the microstructures visualization (needle-shaped cementite, dark regions of ferrite matrix and bainite plates, indicated by dashed circles), these images displayed quantitative information about height distribution (right side of each micrograph). In Fig. 2a, the highest peak of the cementite structure is about $225 \mathrm{~nm}$ far from the deepest region of the $\alpha$-ferrite matrix. In Fig. $2 b$, the value $1.11 \mu \mathrm{m}$ is the distance between the scratch bottom and the highest peak hill on the scratch edge.

Biocorrosion produced morphological alterations in the untreated steel, easily identified by SEM. It can be observed in Fig. 3a, some pits (cavities on the surface, indicated by the smaller arrows) and also new structures (clear region, indicated by the larger arrow). The EDS microanalysis on these new structures revealed high contents of oxygen (32\% in weight), which has not been detected in the metal before biocorrosion. This result strongly suggests that oxide formation originated these new morphological structures.

As can be seen in Fig. 3b, the surface of a nitrocarburized 4340 steel after the biocorrosion process showed no significant morphological alterations due to biocorrosion. In addition, the EDS microanalysis on the nitrocarburized 4340 steel has detected only $7 \%$ of oxygen content after biocorrosion. These results supported the finding that nitrocarburizing treatment of the metal is also an effective protection against biocorrosion.

(a)

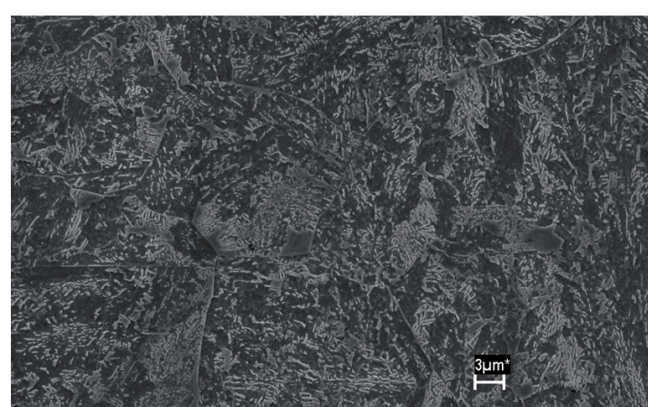

(b)

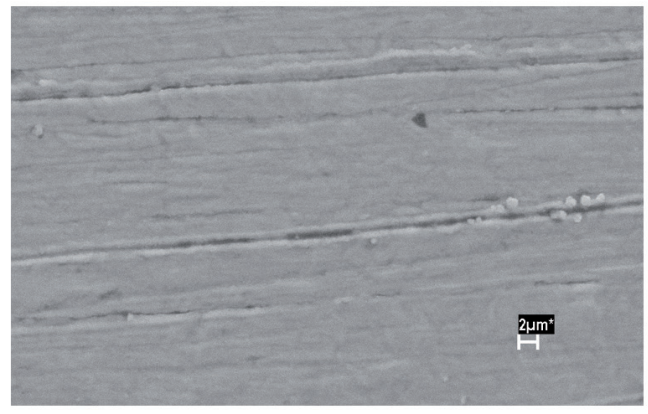

Figure 1. Scanning electron micrographs of (a) untreated and (b) nitrocarburized 4340 steel.

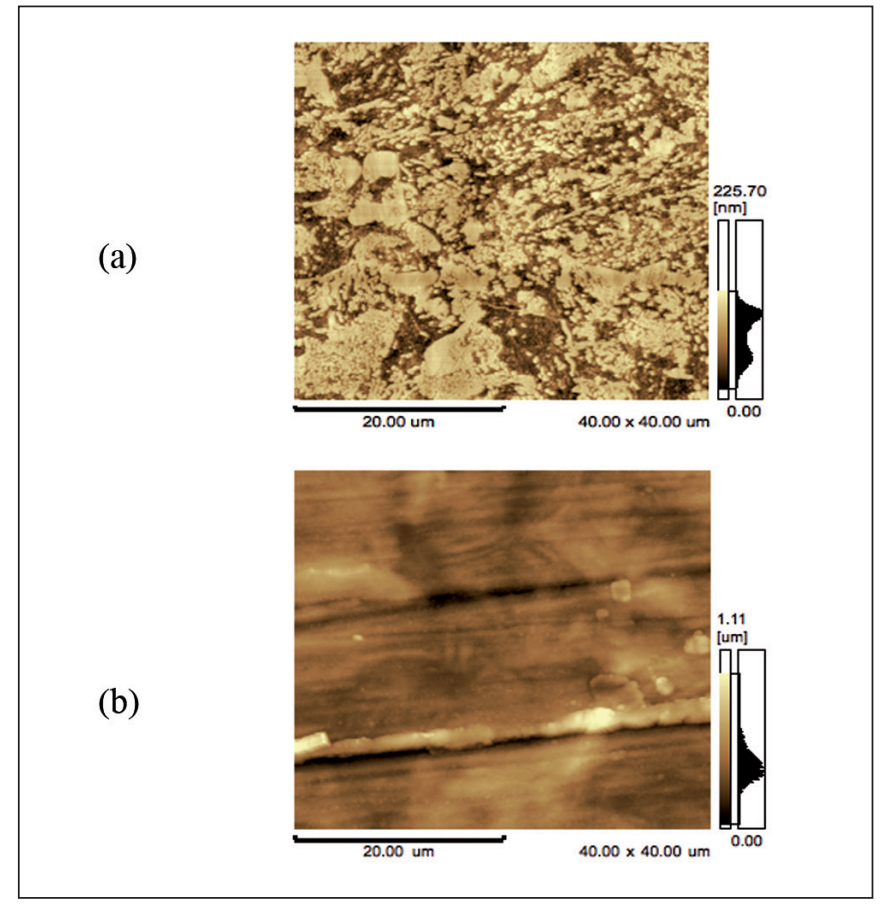

Figure 2. Bi-dimensional visualization of atomic force micrographs of (a) untreated and (b) nitrocarburized 4340 steel.

(a)

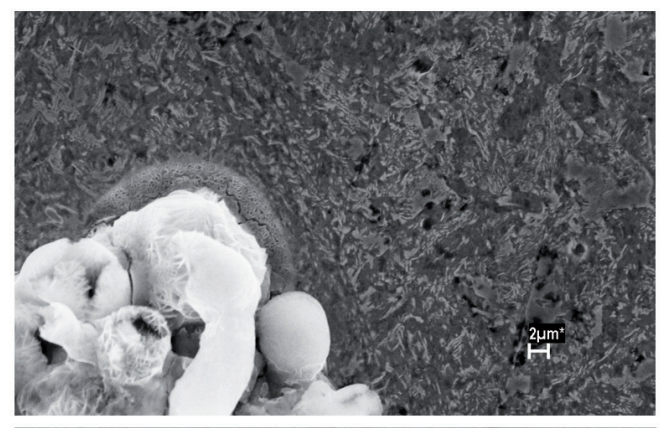

(b)

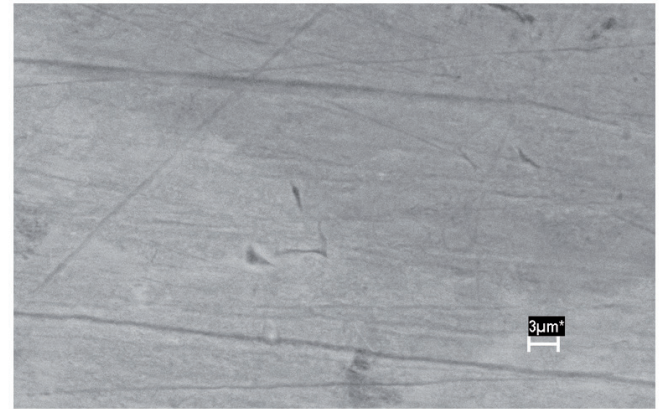

Figure 3. Scanning electron micrographs of

(a) untreated (indicating biological corrosion) and (b) nitrocarburized 4340 steel.

Figure 4 shows AFM images of untreated and treated steels after biocorrosion. In Fig. 4a, in addition to some pits of corrosion (white arrows), it can be seen that all the structures have lost their original morphology. Topography 
also changed drastically, increasing the height distribution scale to $663 \mathrm{~nm}$. On the other hand, Fig. $4 \mathrm{~b}$ corroborates Fig. 3b: no appreciable changes in morphology and topography of the nitrocarburized steel surface were measured by AFM after biocorrosion.

(a)

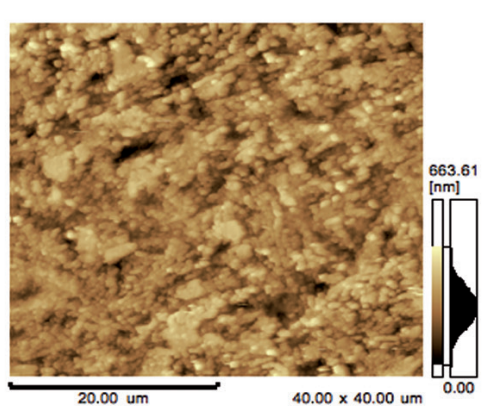

(b)

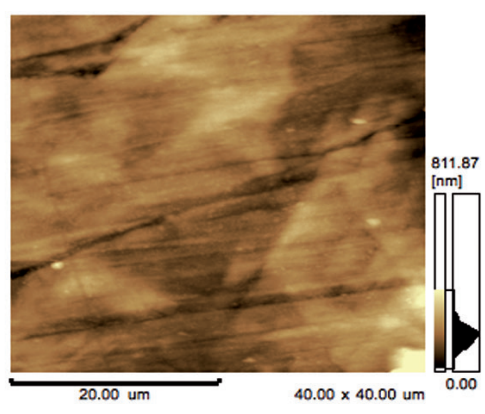

Figure 4. bi-dimensional visualization of atomic force micrographs of untreated (a) and treated (b) 4340 steel after biocorrosion.

\section{Conclusion}

Biocorrosion influenced by Penicillium candidum resulted in severe surface deterioration on untreated 4340 steel, with pits and oxide formation. However, no noteworthy morphological and topographical changes were observed in the nitrocarburized steel coupons.

The plasma nitrocarburizing treatment on the multiphase 4340 steel was also effective to improve the resistance against biocorrosion by $P$. candidum fungi, suggesting that it should be tested with other microorganisms and other metals and alloys used in the aerospace and aviation industries.

\section{Acknowledgements}

To CNPq for the PIBIC/CNPq-IEAv grant, to Capes for the project financial support (Capes Pró-Defesa
014/08), to FAPESP (grant \#2014/05884-7), to Instituto Tecnológico de Aeronáutica, for the AFM facility, and to NUFABI - UNIVAP, for the microbiology infrastructure.

\section{Referências}

1. Baggio-Scheid, V.H.; Abdalla, A.J.; Vasconcelos, G., Plasma Nitrocarburing and Laser Hardening Duplex Treatment of AISI 4340 Steel, In: International Conference on Metallurgical Coating and Thin Films, Proc. of the CMCOTF-2009, San Diego, EUA, 2009.

2. Abdalla, A.J.; Carrer, I.R.; Barboza, M.J.R.; Moura Neto, C., Estudo de fluência em aços 4340 com diferentes microestruturas e tratamento de carbonitretação a plasma. Anais do 19 Congresso Brasileiro de Engenharia e Ciência de Materiais, November 25-29, 2010, Campos do Jordão, SP, ref. 317-045. Available in http://www.cbecimat.com. br/detalhes.asp?Id=886, accessed in July 18th, 2011.

3. Ranieri, A.; Scheid, V.H.B.; Suzuki,P.A; Abdalla, A.J., Plasma nitrocarburizing treatment of 4340 steel. Proc. of the COBEM 2009 - International Congress of Mechanical Engineering, Gramado, RS, 01 2009, pp. 01-06.

4. Abdalla, A.J.; Baggio-Scheid, V.H., Tratamentos termoquímicos a plasma em aços carbono. Corros. Prot. Mater., 25 (2006) 92-96.

5. Videla, H.A., Manual of biocorrosion. 1rst ed., CRC Press, Inc., 1996.

6. Costerton, J.W.; Geesey, G.G., The microbial ecology of surface colonization and of consequent corrosion. In Biologically induced corrosion, ed. S. C. Dexter. National Association of Corrosion Engineers, Houston, TX, 223232, apud Videla, H. A., Microbially induced corrosion: an updated overview. Int. Biodet. \& Biodegrad., 48 (2001) 176-201.

7. Rajasekaranr, A.; Ting,Y.P., Microbial corrosion of aluminum 2024 aeronautical alloy by hydrocarbon degrading bacteria Bacillus cereus ACE4 and Serratia marcescens ACE2. Ind. Eng. Chem. Res., 49 (2010) 6054-6061.

8. Buddie, A.G.; Bridge, P.D.; Kelley,J.; Ryan, M.J., Candida keroseneae sp. nov., a novel contaminant of aviation kerosene. Lett. Appl. Microbiol., 52 (2010) 70-75.

9. Edmonds, P.; Cooney, J.J., Identification of microorganisms isolated from jet fuel systems. Appl. Microbiol., 15 (1967) 411-416.

10. Little, B.J.; Lee, J.S., Microbiologically Influenced Corrosion. Hoboken, N. J., USA, John Wiley and Sons, 2007.

11. Papagianni, M., Fungal morphology and metabolite production in submerged mycelial processes. Biotechnol. Adv., 22 (2004) 189-259. 
12. Ruiz, B.; Farré, A.; Langley, E.; Masso, F.; Sánchez, S., Purification and Characterization of an Extracellular Lipase from Penicillium candidum. Lipids 36 (2001), 283-289.

13. Ortiz-Vásquez, E.; Granadis-Baez, M.; Rivera-Muñoz, G., Effect of culture conditions on lipolytic enzime production by Pnicillium candidum in a solid state fermentation. Biotechnol. Adv., 11 (1993) 409-416.

14. Videla, H. A., Biotecnologia- Corrosão microbiológica. 1rst ed., Edgard Blücher Ltda, São Paulo, 1986.
15. Silva, A. M.A.; Santiago, T. M.; Alves, C.R.; Guedes, M.I.F.; Freire, J.A.K.; Vieira, R.H.S.F.; Da Silva, R.C.B., An evaluation of the corrosion behavior of aluminum surfaces in presence of fungi using atomic force microscopy and other tests. Anti-corrosion Methods and Materials, 54 (2007) 289-293.

16. Smirnov, V.F.; Belov, D.V.; Sokolova, T N.; Kuzina, O.V.; Kartashov, V.R., Microbiological corrosion of aluminum alloys. Applied Biochemistry and Microbiology, 44 (2008) 192-196. 